\title{
Les vêtements liturgiques dits de Saint Valère. Leur place parmi les tissus hispano-mauresques du XIIIe siècle
}

\section{Rosa Maria Martin I ros}

\section{(2) OpenEdition} Journals

Édition électronique

URL : https://journals.openedition.org/tc/329

DOI : $10.4000 /$ tc.329

ISSN : 1952-420X

Éditeur

Éditions de l'EHESS

\section{Édition imprimée}

Date de publication : 1 janvier 2000

ISSN : 0248-6016

\section{Référence électronique}

Rosa Maria Martin I ros, "Les vêtements liturgiques dits de Saint Valère. Leur place parmi les tissus hispano-mauresques du XIIIe siècle», Techniques \& Culture [En ligne], 34 | 2000, mis en ligne le 26 octobre 2005, consulté le 29 septembre 2022. URL : http://journals.openedition.org/tc/329 ; DOI : https://doi.org/10.4000/tc.329

Ce document a été généré automatiquement le 29 septembre 2022

Tous droits réservés 
Les vêtements liturgiques dits de Saint Valère. Leur place parmi les tissus hispano-mauresques du XIIIe siècle

Rosa Maria Martin I ros 